\title{
EDUKASI DEMAM BERDARAH PADA WARGA DI JALAN GEDONGSONGO BARAT II RT 02 RW 02 KELURAHAN MANYARAN SEMARANG
}

\author{
Ratna Shintia Defi ${ }^{1}$, \\ Maura Sonia Larasati ${ }^{2}$, Risto Adiparta ${ }^{2}$, \\ Clarissa Sudirman ${ }^{2}$, Angela Fasha Septiani Simamora ${ }^{2}$ \\ ${ }^{1,2}$ Fakultas Kedokteran Universitas Katolik Soegijapranata Semarang, Indonesia \\ Korespondensi Penulis: \\ Nama $\quad$ : dr. Ratna Shintia Defi, M.biomed \\ Alamat : Citra Sun Garden blok G 55 \\ Nomor Telepon : 081314179293 \\ Email : : ratna@unika.ac.id
}

\begin{abstract}
Abstrak
Prioritas masalah penyakit demam berdarah dan upaya pencegahan didapatkan berdasarkan hasil observasi dan wawancara dengan masyarakat di Desa Manyaran tepatnya di Jalan Gedongsongo Barat II RT 02 RW 02. Intervensi berdasarkan prioritas masalah berupa kesehatan pendidikan kepada perwakilan masyarakat setempat. Kegiatan ini bertujuan untuk memberikan pengetahuan dan pemahaman tentang penyakit demam berdarah, upaya pencegahan dan peningkatan kesadaran tentang penyakit demam berdarah bagi warga di Jalan Gedongsongo Barat II RT 02 RW 02 Manyaran. Metode yang digunakan dalam penyuluhan adalah observasi dan wawancara dengan warga di Jalan Gedongsongo Barat II RT02 RW02 Desa Manyaran Semarang. Hasil yang didapat setelah penyuluhan, sebagian besar warga sudah paham tentang penyakit demam berdarah dan cara pencegahannya.
\end{abstract}

Kata kunci: DBD, pengetahuan, perilaku, sikap, pencegahan.

\begin{abstract}
Priority problems regarding dengue fever and prevention efforts were obtained based on the results of observations and interviews with the community in Manyaran Village, precisely on Jalan Gedongsongo Barat II RT 02 RW 02. Intervention based on the priority of the problem was in the form of health education to local community representatives. This activity aims to provide knowledge and understanding about dengue fever, prevention efforts and increase awareness about dengue fever for residents on Jalan Gedongsongo Barat II RT 02 RW 02 Manyaran. The method used in the counseling is observation and interviews with residents on Jalan Gedongsongo Barat II RTO2 RW02, Manyaran Village, Semarang. The result obtained after education, most of residents understand about dengue fever and how to prevent it.
\end{abstract}

Kata kunci: $D H F$, knowledge, behavior, attitude, prevention.

\section{Pendahuluan}

\section{Latar Belakang}

Demam berdarah adalah virus yang ditularkan melalui perantara nyamuk dan merupakan penyakit virus yang ditularkan arthropoda di dunia. Ini juga dikenal sebagai demam breakbone karena tingkat keparahannya berupa kejang otot, nyeri sendi, dan demam tujuh hari. DBD 
ditularkan melalui gigitan nyamuk dari genus Aedes, terutama Aedes aegypti atau Aedes albopictus. ${ }^{1}$

Pembawa dan penyebar penyakit DBD yaitu Aedes aegypti menyukai lingkungan dengan kualitas yang buruk, yang ditandai dengan permukiman padat penduduk dengan lingkungan yang kurang cahaya matahari, lembab, gelap, dekat dengan sungai dengan alirannya lambat karena adanya banyak sampah sehingga menimbulkan genangan sebagai tempat perkembangbiakan nyamuk Aedes aegypti. Aedes aegypti yang lebih menyukai hidup di permukiman penduduk dan menyukai darah manusia, berbeda dengan Aedes albopictus yang habitatnya di kebun dan menghisap darah hewan. ${ }^{2}$

Pada kegiatan edukasi kali ini penulis melakukan penyuluhan kesehatan mengenai penyakit demam berdarah. Kegiatan ini dilakukan di salah satu kelurahan yang berada di Semarang, tepatnya di Kelurahan Manyaran di Jalan Gedongsongo BaratII RT 02 RW 02. Penulis mengajak warga di Kelurahan Manyaran untuk bersama-sama melakukan upaya pencegahan penyebaran demam berdarah sehingga dapat mengurangi tingkat terjadinya penyakit demam berdarah.

Penulis memilih edukasi kesehatan mengenai penyakit demam berdarah karena tingginya kasus penyakit demam berdarah selama beberapa tahun ini yang tersebar di berbagai wilayah di Indonesia. Berdasarkan data Kementrian Kesehatan Indonesia kasus Demam Berdarah Dengue di Indonesia hingga November 2020 sebanyak 95.893 kasus. ${ }^{3}$ Selain itu, di Jalan Gedongsongo Barat II RT 02 RW 02 Kelurahan Manyaran tidak semua warga membersihkan bak mandi secara berkala dan hanya membersihkan selokan ketika sudah terhambat, kondisi jalan yang tidak rata serta seringnya terjadi hujan yang membuat pengaruh besar terhadap perkembangbiakan nyamuk Aedes aegypti, oleh karena itu penulis memutuskan untuk melakukan penyuluhan di di Jalan Gedongsongo Barat II RT 02 RW 02 Kelurahan Manyaran. Pemberian edukasi kepada warga RT 02 RW 02 Kelurahan Manyaran merupakan bentuk peran serta dalam menyukseskan gerakan pemerintah untuk mengurangi dan mencegah penyebaran virus dengue, serta menerapkan Pemberantasan Sarang Nyamuk (PSN) 3M Plus dimana M yang pertama yaitu Menguras yang merupakan kegiatan membersihkan atau menguras tempat yang sering menjadi penampungan air seperti contohnya bak mandi, toren air, drum dan tempat penampungan air lainnya. M yang kedua yaitu Menutup, merupakan kegiatan menutup rapat tempat - tempat penampungan air seperti bak air maupun drum. Menutup sendiri dapat diartikan sebagai kegiatan untuk mengubur barang bekas di dalam tanah agar tidak membuat 
lingkungan semakin kotor dan menimbulkan sarang nyamuk aedes aegypti. M yang ketiga yaitu Memanfaatkan Kembali limbah bekas atau mendaur ulang barang bekas (kaleng bekas, botol bekas) yang berpotensi menjadi tempat berkembang baik nyamuk demam berdarah. Plus merupakan upaya pencegahan tambahan seperti penggunaan bubuk larvasida, menggunakan obat anti nyamuk dan gotong royong membersihkan lingkungan.

Dalam program penyebaran penyakit demam berdarah penulis berencana mengadakan edukasi kesehatan mengenai demam berdarah sebagai upaya menyukseskan program 3M yang di programkan oleh pemerintah yaitu dengan menguras, menutup dan mendaur ulang barang bekas.

Kegiatan ini dilakukan untuk membantu warga di daerah tersebut supaya dapat memahami pentingnya menjaga kebersihan lingkungan sekitar dan menerapkan 3M di setiap rumah. Kegiatan ini juga mengedepankan tingkat kepedulian terhadap warga sekitar yang membuat penulis ikut menyukseskan program pemerintah di dalam bidang kesehatan. Kegiatan yang sudah dilakukan membantu warga yang tinggal di Jalan Gedongsongo Barat II RT 02 RW 02 Kelurahan Manyaran dalam upaya pencegahan penyebaran penyakit demam berdarah.

\section{Tujuan}

Tujuan dari kegiatan penyuluhan kesehatan field lab ini:

1. Mengetahui dan mengidentifikasi sejauh mana pemahaman warga di Jalan Gedongsongo Barat II RT 02 RW 02 Manyaran tentang penyakit demam berdarah.

2. Melakakukan edukasi kesehatan tentang pengetahuan, sikap, perilaku dan upaya pencegahan dari penyakit demam berdarah

\section{Metode}

Penulis melakukan identifikasi masalah dengan metode observasi lingkungan melalui wawancara mendalam terhadap 25 subjek penelitian, yakni masyarakat di Jalan Gedongsongo Barat II RT 02 RW 02 Kelurahan Manyaran. Wawancara mendalam dilakukan secara lisan berdasarkan daftar pertanyaan wawancara mendalam yang sudah disusun dari beberapa tema yaitu mengenai tingkat pengetahuan masyarakat terhadap demam berdarah, respon masyarakat untuk menyikapi dan berperilaku dalam pencegahan penyakit Demam Berdarah. Permasalahan kesehatan masyarakat di Kelurahan Manyaran tepatnya di Jalan Gedongsongo Barat II RT 02 RW 02 yang telah diobservasi oleh penulis yang utama berupa bak mandi atau penampungan air di 
beberapa rumah menjadi sarang bagi jentik-jentik nyamuk, selain itu selokan di beberapa rumah yang mampat karena alirannya tidak lancar sehingga di area tertentu terdapat genangan air selokan yang cukup mempengaruhi rumah warga saat musim hujan, warga lebih gemar membuang5 atau menjual barang-barang bekas agar tidak menjadi sarang nyamuk untuk berkembang biak, namun di beberapa rumah memanfaatkan barang-barang bekas seperti kaleng bekas, botol bekas, dan sebagainya menjadi pot atau kerajinan tangan anak. Hampir semua masyarakat dewasa yang sudah bekerja dan melakukan aktivitas bekerjanya dari pagi hingga sore hari setiap hari di luar area tempat tinggalnya. Berdasarkan dokumentasi dan informasi yang ada, masyarakat sering mengadakan kegiatan kerja bakti rutin setiap seminggu sekali yang diikuti oleh bapak-bapak atau kepala keluarga masing-masing. Penyuluhan kesehatan ini bertujuan untuk meningkatkan pengetahuan masyarakat mengenai penyakit demam berdarah dan upaya pencegahannya, selain itu meningkatkan kesadaran masyarakat akan pentingnya menyikapi dan menerapkan upaya pencegahan dalam kehidupan sehari-hari.

Sasaran penyuluhan terutama kepada 25 warga yang tergolong dewasa muda hingga dewasa madya terutama dengan gender wanita. Penulis memilih sasaran dewasa muda hingga dewasa madya terutama dengan gender wanita karena pertimbangan bahwa hampir seluruh kegiatan seperti pengurasan bak mandi, penutupan tempat air, dan kegiatan mendaur ulang kembali barang bekas dominan dilakukan oleh ibu-ibu rumah tangga. Strategi yang penulis lakukan untuk melibatkan sasaran sudah penulis mulai semenjak survei yang penulis lakukan dimana saat itu anggota penulis sudah mulai mempublikasikan mengenai penyuluhan yang akan penulis lakukan di salah satu rumah warga dan mengundang warga untuk hadir dalam kegiatan tersebut.

Penulis melakukan identifikasi masalah dengan metode observasi lingkungan melalui kegiatan wawancara kepada sampel masyarakat di Kelurahan Manyaran tepatnya di Jalan Gedongsongo Barat II RT 02 RW 02. Kegiatan wawancara dilakukan secara lisan berdasarkan daftar pertanyaan kuisioner yang sudah disusun dari beberapa tema yaitu mengenai tingkat pengetahuan masyarakat terhadap demam berdarah, respon masyarakat untuk menyikapi dan berperilaku dalam pencegahan penyakit Demam Berdarah.

Edukasi Demam Berdarah Pada Warga di Jalan Gedongsongo Barat II RT 02 RW 02 Kelurahan Manyaran Semarang telah dilaksanakan pada salah satu rumah warga. Yang pelaksanaannya dilakukan pada hari Sabtu, 19 Juni 2021 yang dimulai pada pukul 16.00 WIB dan 
berakhir pada pukul 17.15. Penyuluhan berlangsung selama 1 jam 15 menit dengan dihadiri oleh 9 peserta yang merupakan ibu rumah tangga dengan kategori usia dewasa muda sampai dewasa madya. Pada awalnya penulis menetapkan sasaran sejumlah 25 -30 warga di Jalan Gedongsongo Barat II RT 02 RW 02 Kelurahan Manyaran, namun sasaran ini berubah menjadi 10-15 warga ketika peningkatan kasus COVID- 19 yang cukup tinggi terutama di daerah Kelurahan Manyaran dan cuaca yang tidak mendukung seperti hujan petir di sore hari serta menerapkan protokol kesehatan (physical distancing).

\section{Hasil}

\section{Karakteristik Populasi}

Manyaran Merupakan salah satu kelurahan di Kecamatan Semarang Barat Provinsi Jawa Tengah yang terbagi menjadi 11 RT dan 99 RW dengan luas wilayah sebesar $150 \mathrm{H}$. Kepadatan Penduduk di wilayah Semarang Barat adalah 6848 jiwa/ $\mathrm{km}^{2}$. Salah RT/RW di Manyaran adalah RT 02 RW 02 yang terdiri dari 41 rumah dengan 60 Kepala Keluarga. Sebanyak 218 jiwa dengan rentang usia dewasa, dewasa belum menikah sebanyak 21 jiwa, dewasa madya 108 jiwa, dewasa tua atau lansia 28 jiwa, anak-anak 61 jiwa. ${ }^{4}$ Warga RT 02 RW 02 Kelurahan Manyaran biasa melakukan kegiatan seperti kerja bakti yang diikuti oleh para warga laki-laki setiap seminggu sekalidan biasanya diadakan pada akhir pekan. Pada saat pandemi seperti ini, seluruh kegiatansosial seperti kerja bakti pada akhir pekan di lingkungan ini ditiadakan. Kegiatan lain berupa olahraga bersama yaitu tenis meja yang dilakukan setiap hari saat sepulang kerja atau pada sore hingga malam hari sekitar pukul 17.00-24.00 WIB. Kegiatan olahraga bersama tetap dilaksanakan selama adanya pandemi COVID-19 dengan tetap mematuhi protokol kesehatan yang telah ditetapkan. Mayoritas warga RT 02 RW 02 Kelurahan Manyaran telah menempuh pendidikan terakhir yaitu di tingkat SMA/sederajat, dan bekerja di luar rumah.

\section{Karakteristik Tempat Tinggal}

Berdasarkan hasil observasi lingkungan sekitar di Jalan lingkungan Gedongsongo Barat II RT 02 RW 02 Kelurahan Manyaran, didapatkan hasil bahwa jarak rumah ke rumah berdempetan, jarak antara dinding rumah yang satu dengan yang lainnya berhimpitan. Terdapat 41 rumah dengan 60 Kepala Keluarga. Sebanyak 218 jiwa tinggal di daerah tersebut yang menandakan bahwa wilayah di Jalan lingkungan Gedongsongo Barat II RT 02 RW 02 Kelurahan Manyaran adalah wilayah yang padat penduduk. 
Setiap rumah warga memiliki ventilasi yang baik sehingga sirkulasi udaranya baik dan cahaya matahari dapat masuk ke dalam rumah. Setiap rumah juga memiliki minimal satu kamar mandi namun di beberapa rumah dihuni oleh lebih dari 1 keluarga. Selain itu, beberapa rumah warga mendapatkan air yang keruh sehingga harus menguras bak mandi setidaknya seminggu sekali, namun ada pula yang mengurasnya sebulan sekali sehingga terdapat jentik nyamuk pada genangan air yang terdapat pada penampungan air seperti bak mandi, gentong, dan ember.

Pada sebagian rumah warga terlihat cukup terawat namun pada beberapa rumah lainnya ditemukan tumpukan sampah bangunan yang juga salah satu dampak dari tanah longsor di sebuah area, serta terdapat masalah saluran air yang terhambat oleh sampah dan aliran air yang tidak lancar sehingga di beberapa area rumah terkena dampak meluapnya air dari saluran air yang kotor karena dapat memungkinkan menjadi sarang nyamuk penyebab DBD.

\section{Faktor Risiko}

Berdasarkan analisis situasi dan masalah kesehatan yang penulis temukan, maka terdapat beberapa faktor resiko yang memungkinkan timbulnya Demam Berdarah Dengue pada warga di Jalan lingkungan Gedongsongo Barat II RT 02 RW 02 Kelurahan Manyaran. Faktor resiko tersebut ialah:

\section{Faktor risiko perilaku}

Kegiatan pemeriksaan jentik berkala oleh jumantik yang diadakan setiap hari jumat belum sepenuhnya efektif karena masih ditemukan jentik nyamuk pada tempat penampungan air seperti bak mandi, gentong, dan ember di beberapa rumah warga. Tidak semua warga menguras bak mandi sesuai dengan anjuran yaitu seminggu dua kali. Namun beberapa warga juga telah menerapkan anjuran tersebut serta menggunakan bubuk larvasida sehingga tidak didapati jentik nyamuk. Warga tidak rutinmembersihkan saluran air dan hanya membersihkan saluran air ketika sudah tersumbat oleh sampah yang menyebabkan aliran air tidak lancar sehingga di beberapa rumah terkena dampak meluapnya air dari selokan.

2. Faktor risiko lingkungan

Pada lingkungan tempat tinggal warga, terdapat selokan yang tersumbat oleh sampah dan aliran air yang tidak lancar dikarenakan posisi jalan yang tidak rata sehingga di beberapa area rumah terkena dampak meluapnya air dari selokan yang tidak sehat karena dapat memungkinkan menjadi sarang nyamuk penyebab DBD. ${ }^{5}$ 
3. Iklim dan cuaca

Iklim dan cuaca juga berpengaruh pada perkembangbiakan nyamuk Aedes aegypti. Pada musim hujan memungkinkan tersedianya air dalam media seperti pot bunga, kaleng bekas dan tumpukan sampah bangunan akan menimbulkan sarana bagi telur nyamuk menetas dan setelah 10 - 12 hari akan berubah menjadi nyamuk. Bila manusia digigit oleh nyamuk yang membawa virus dengue maka dalam 4 - 7 hari kemudian mulai timbul gejala DBD. Pada waktu dimulainya musim hujan hingga terjadinya insiden DBD adalah sekitar 3 minggu. ${ }^{6}$

\section{Perilaku Personal Hygiene}

Berdasarkan hasil penelitian perilaku responden didapatkan jawaban dari pertanyaan yang pertama mengenai pengadaan fogging yang dilakukan di Gedongsongo Barat RT 02 RW 02 sebagian menjawab belum pernah diadakannya kegiatan tersebut. Namun ada yang menjawab sudah pernah diadakan sebelumnya tetapi saat ini tidak dilakukan lagi sebagai alasannya karena adanya pandemi COVID-19. Selanjutnya hasil penelitian observasi mengenai penampungan air, sebagian menggunakan bak mandi terbuka sehingga hal tersebut dapat dijadikan media perkembangbiakkan jentik nyamuk Aedes aegepty. Perilaku responden mengenai pencegahan DBD terkait pengurasan bak mandi, tidak semuanya melakukan sesuai anjuran yaitu dua kali dalam seminggu. Hasil pengamatan tempat tinggal, beberapa rumah juga ada yang tidak mempunyai tempat penampungan air karena menggunakan pancuran. Dari hasil wawancara didapatkan bahwa bubuk larvasida digunakan setelah menguras tempat penampungan air, tetapi tidak digunakan oleh semua responden penelitian karena harga jual bubuk tersebut yang terbilang mahal. Perilaku responden mengenai pencegahan DBD terkait pengurasan bak mandi, tidak semuanya melakukan sesuai anjuran yaitu dua kali dalam seminggu. Dari pengamatan lingkungan, selokan yang berada di depan rumah dibersihkan satu kali dalam seminggu saat diadakannya kerja bakti di lingkungan Gedong Songo Barat RT 02RW 02.

\section{Kondisi Lingkungan Tempat Tinggal}

Berdasarkan hasil wawancara dan observasi pada RT 02 RW 02 Gedongsongo Barat, standar ruang lingkup kesehatannya ditemukan masalah seperti terdapat selokan yang terhambat oleh sampah dan aliran air yang tidak lancar sehingga di beberapa area rumah terkena dampak meluapnya air selokan, yang dimana hal tersebut dapat memungkinkan bersarangnya nyamuk penyebab DBD. Selain itu, beberapa rumah warga mendapatkan air yang keruh karena kondisi geologis atau struktur tanah yang kurang baik sehingga harus menguras bak mandi setidaknya 
seminggu sekali.

\section{Hasil Edukasi atau Promosi Kesehatan}

WHO menetapkan Indonesia sebagai negara dengan kasus DBD tertinggi di Asia Tenggara pada tahun 1968 sampai 2009. ${ }^{7}$ Indonesia merupakan salah satu negara yang mempunyai kasus edemis cukup tinggi. Demam Berdarah Dengue mengalami epidemi setiap 4 hingga 5 tahun sekali. Menurut data yang diperoleh Kementerian Kesehatan Republik Indonesia pada tahun 2017 Provinsi Jawa Tengah, mengenai DBD masih termasuk permasalahan yang serius. Dibuktikan dengan adanya 35 kabupaten dan kota yang sudah pernah terjangkit DBD. 8,9 Dari hal tersebut penulis menentukan Need Assesment dengan menyusun prioritas masalah yang ada di Kelurahan Manyaran Kecamatan Semarang Barat Kota Semarang yaitu Demam Berdarah Dengue serta Pencegahannya.

Demam berdarah adalah penyakit yang disebabkan oleh virus dengue dan ditularkan melalui gigitan nyamuk Aedes aegepti. Cara penularannya adalah ketika virus dengue yang memiliki 4 jenis serotipe yang disebarkan oleh vektornya yaitu nyamuk Aedes Aegepti. Kemudian nyamuk yang terinfeksi ketika menggigit atau menghisap darah manusia akan menularkan virus tersebut. Tanda dan gejalanya yang pertama adalah demam yang tinggi hingga $40^{\circ} \mathrm{C}$ yang dapat mundul mendadak disertai sakit kepala berat selama 2-7 hari. Kedua adalah ruam/ bintik dan pegal otot, ruam atau bintik terang muncul pertama kali pada bagian bawah, badan, dan lalu menyebar hampirseluruh tubuh. Layuh atau kelemahan otot (myalgial pegal). Ketiga adalah gangguan pencernaan dimana sakit perut terjadi sesekali muncul disertai rasa mual, lalu muntah- muntah dan diare. ${ }^{10,11}$ Siklus hidup nyamuk Aedes Aegepti termasuk siklus hidup sempurna, yaitu telur-larva-pupa-dewasa (7-4 hari). Ciri dari nyamuk Aedes aegepti adalah berwarna hitam belang- belang (loreng) putih pada seluruh tubuh. Jarak terbangnya setinggi 100 meter. Tempat hinggap yang disenangi adalah benda yang tergantung, seperti pakaian, kelambu, atau tumbuh-tumbuhan di dekat tempat berkembangbiaknya. Aktif menggigit di pagi sampai sore hari biasanya ditempat yang agak gelap dan lembab. Jentik selalu bergerak aktif dalam air dari bawah ke atas permukaan secara berulang-ulang.

Tempat-tempat penampungan air bersih di dalam rumah maupun di sekitar lingkungan, seperti:

1. Bak mandi atau WC, tempayan, drumTempat minum burung, vas bunga atau pot tanaman air. 
2. Kaleng bekas, ban bekas, botol, tempurung kelapa dan plastik yang dibuang disembarang tempat.

3. Talang air yang rusak dan saluran air hujan yang tidak lancar

4. Pagar atau potongan bambu yang berlubang.

Pencegahan demam berdarah caranya adalah dengan gerakan PSN DBD. Gerakan PSN (Pemberantasan sarang nyamuk) adalah keseluruhan kegiatan yang dilakukan oleh masyarakat dan pemerintah untuk mencegah penyakit DBD yang disertai pemantauan hasil-hasilnya secara terus menerus. Gerakan PSN DBD dapat dilakukan melalui gerakan 3MPlus. Dalam membasmi jentik nyamuk penularan DBD dengan cara yang dikenal sebagai 3M Plus, langkah-langkahnya berupa: 12

1. Menguras tandon air yang bisa dikuras antara lain bak mandi, bak WC, vas bunga, tempat minum burung.

2. Menutup

Jenis menutup tandon air agar tidak dipakai nyamuk berkembang baik:

a. Menutup tandon dengan rapat agar air yang disimpan tidak ada jentiknya. Jenis tandon ini antara lain gentong, drum, endonir, emberisasi.

b. Menutup tendon agar tidak terisi air.

3. Mengubur

Barang-barang bekas yang dapat menampung air dan tidak akan dimanfaatkan lagi sebaiknya disingkirkan yang mudah adalah dengan mengubur ke dalam tanah.

Pencegahan lainnya yaitu berupa menghindari gigitan nyamuk, langkah-langkahnya yaitu:

1. Pengelolaan Lingkungan

a. Mengeringkan instalasi penampungan air Genangan air, pipa penyaluran, katup pintu air, tempat yang dapat menampung air dan dapat menjadi tempat perindukan jentik Aedes aegypti.

b. Tempat penampungan air di lingkungan rumah tangga.

c. Jambangan dan vas bunga Jambangan bunga dan vas bunga harus dilubangi sebagai lubang pengeringan, vas harus digosok dan dibersihkan

2. Memodifikasi Lingkungan

a. Perbaikan Saluran Air 
b. Talang air/tangki air bawah tanah

c. Tempat perindukan jentik nyamuk termasuk di talang air/tangki bawah tanah, maka strukturnya harus dibuat anti nyamuk.

3. Perlindungan diri

a. Pakaian pelindung

b. Obat nyamuk semprot, bakar.

c. Obat oles anti nyamuk (repellent).

d. Tirai dan kelambu nyamuk

e. Penggunaan tanaman penghala nyamuk

f. Penggunaan bubuk larvasid Plus nya adalah sebagai berikut : ${ }^{13}$

g. Memelihara ikan pemakan jentik nyamuk

h. Gotong-royong membersihkan lingkungan

i. Menggunakan obat anti nyamuk

j. Memperbaiki saluran dan talang air yang tidak lancar.

k. Periksa tempat penampungan air

1. Memberikan bubuk larvasida (abate) pada penampungan air yang susah dikuras

m. Mendaur ulang barang bekas yang dapat menampung air

Pada pelaksanaan intervensi dipengaruhi oleh berbagai faktor baik yang mendukung maupun yang menghambat. Faktor yang mendukung dalam pelaksanaan intervensi berupa keterbukaan warga setempat yang mengijinkan anggota penulis untuk melakukan wawancara dan observasi pada rumah warga.

Peserta pada program intervensi ini mencapai target yang sudah ditentukan oleh penulis, walaupun adanya pengurangan sasaran penyuluhan dikarenakan kondisi yang tidak memungkinkan. Proporsi kelompok sasaran menerima intervensi sebesar 90\% dari total apabila menggunakan jumlah peserta kegiatan edukasi yang tergolong sebagai ibu rumah tangga kategori dewasa muda-dewasa madya.

Tabel 2. Evaluasi Hasil Edukasi Partisipan

\begin{tabular}{|c|c|c|}
\hline No. & Nama & Nilai \\
\hline 1. & Ny. S & 92 \\
\hline 2. & Ny. Y & 67 \\
\hline
\end{tabular}




\begin{tabular}{|c|c|c|}
\hline No. & Nama & Nilai \\
\hline 3. & Ny. A & 92 \\
\hline 4. & Ny. M & 58 \\
\hline 5. & Ny. NS & 67 \\
\hline 6. & Ny. S & 83 \\
\hline 7. & Ny. UN & 67 \\
\hline 8. & Ny. DA & 75 \\
\hline 9. & Ny. YS & 67 \\
\hline
\end{tabular}

\section{Diskusi}

Demam Berdarah Dengue (DBD) adalah penyakit infeksi virus akut yang disebabkan oleh virus dengue yang tanda dan gejalanya adalah demam 2 hingga 7 hari disertai dengan manifestasi perdarahan, trombositopenia, peningkatan hematokrit, efusi pleura, hipoalbiminemia. Dapat juga disertai dengan tanda dan geja berupa ruam kulit atau otot yang merasa pegal (myalgia). ${ }^{14}$ Kegiatan pemberdayaan dan peningkatan peran serta untuk meningkatkan program pengendalian Demam Berdarah Dengue dilaksanakan di masyarakat selalu melibatkan proses komunikasi yaitu dengan diadakannya penyuluhan edukasi. Sebelum diadakan edukasi penulis melakukan pengambilan sampel, dilakukan pendataan untuk mengetahui jumlah populasi yang akan ditetapkan sebagai responden. Berdasarkan data yang ada RT 02/ RW 02 Kelurahan Manyaran di Kecamatan Semarang Barat Kota Semarang terdiri dari 41 rumah dengan 60 Kepala Keluarga. Akan tetapi pada saat observasi untuk mendapatkan sampel, penulis menggunakan 26 orang warga dari 22 rumah tangga dilingkungan RT 02/ RW 02, Kelurahan Manyaran Kecamatan Semarang Barat. Sebelum diadakannya edukasi kepada warga sekitar, penulis melakukan observasi serta wawancara mengenai kejadian demam berdarah yang dialami oleh anggota keluarga responden dalam kurun waktu 6 bulan ini. Lalu pemahaman mengenai pengetahuan, sikap, perilaku serta upaya pencegahannya yang berkaitan dengan demam berdarah. Data yang diperoleh dari hasil wawancara dan observasi memiliki jawaban yang berbeda-beda untuk setiap pertanyaan yang diajukan. Pencegahan demam berdarah sangat penting, karena dapat mempengaruhi kesehatan lingkungan tempat tinggal dan individu. Intervensi yang telah dilakukan berupa penyuluhan mengenai Penyuluhan Demam Berdarah dan Pencegahannya. Edukasi ini sangat penting 
dilakukan untuk meningkatkan kesadaran dan pemahaman warga sekitar tentang pentingnya menjaga kebersihan tempat tinggal dan kesehatan individu. Dengan meningkatnya kesadaran dan pengetahuan, maka warga sekitar mudah mengatasi permasalahan kesehatan yang ada di lingkungan tersebut.

Edukasi yang akan dilakukan dengan tindakan berupa sosialisasi melalui presentasi atau pemaparan materi dan dilanjutkan dengan tanya jawab terkait materi. Media penyampaian materi yang digunakan adalah melalui PPT (Microsoft Office Power Point) dengan tujuan meberikan kemudahan untuk dipamahi karena ditampilkan dalam bentuk slide. Media yang digunakan lainnya adalah berupa poster yang berisi tentang hal-hal yang berkaitan dengan upaya pencegahan demam berdarah. Media promosi kesehatan yang banyak digunakan adalah poster, dimana poster menggunakan unsur visual seperti kata-kata atau gambar yang menarik perhatian, sehingga dapat menarik orang yang mempunyai minat khusus. Intervensi yang dilakukan atas masalah yang ada pada warga sekitar memiliki kesan yang positif dimana dapat dilihat dari sikap keterbukaan warga sekitar ketika diwawancarai dan dilakukan observasi pada tempat tinggal serta partisipasi yang baik saat adanya kegiatan edukasi dengan bukti warga yang hadir sangat antusias memberikan pertanyaan kepada pembicara mengenai materi yang sudah dipaparkan. Kesan positif lainnya adalah warga yang hadir dalam kegiatan edukasi mampu menjawab pertanyaan pada lembar feedback mengenai materi yang sudah diberikan serta memberikan kritik dan saran terhadap presentasi yang sudah dilaksanakan agar lebih baik lagi untuk kedepannya. Kegiatan edukasi berlangsung lancar karena dilaksanakannya sesuai dengan protokol kesehatan yang berlaku. Edukasi yang dilaksanakan dikatakan berhasil dikarenakan output yang diharapkan tercapai. Dimana partisipan yang hadir dapat menjawab lembar feedback yang diberikan dan rata-rata nilai partisipan melebihi persentase output yang ditargetkan yaitu 74,2. Output yang diharapkan yaitu sebesar 60\% warga di Jalan Gedongsongo Barat II RT 02/R2 02 Kelurahan Manyaran yang mengikuti edukasi paham mengenai pengetahuan, sikap, perilaku serta upaya pencegahannya.

\section{Tabel 3. Data Responden}

\begin{tabular}{ccc}
\hline No. & Nama & Usia \\
\hline 1. & Ny. K & 40 \\
\hline 2. & Ny. SS & 36 \\
\hline 3. & Tn. E & 42 \\
\hline
\end{tabular}




\begin{tabular}{|c|c|c|}
\hline No. & Nama & Usia \\
\hline 4. & Ny. S & 45 \\
\hline 5. & Ny. N & 42 \\
\hline 6. & Ny. V & 38 \\
\hline 7. & Tn. S & 39 \\
\hline 8. & Tn. S & 41 \\
\hline 9. & Ny. NS & 38 \\
\hline 10. & Ny. N & 37 \\
\hline 11. & Tn. AB & 41 \\
\hline 12. & Ny. A & 35 \\
\hline 13. & Tn. S & 49 \\
\hline 14. & Ny. W & 33 \\
\hline 15. & Tn. A & 36 \\
\hline 16. & Tn. B & 28 \\
\hline 17. & Ny. R & 26 \\
\hline 18. & Ny. N & 30 \\
\hline 19. & Ny. A & 36 \\
\hline 20. & Ny. I & 45 \\
\hline 21. & Ny. AM & 20 \\
\hline 22. & Ny. YF & 32 \\
\hline 23. & Ny. R & 23 \\
\hline 24. & Ny. K & 65 \\
\hline 25. & Ny. AA & 33 \\
\hline 26. & Ny. S & 45 \\
\hline
\end{tabular}

\section{Kesimpulan}

Dari pelaksanaan edukasi yang telah dilakukan penulis, dapat diambil kesimpulan yaitu warga di Gedong Songo Barat RT 02 RW 02 memiliki masalah kesehatan berupa kurangnya kesadaran untuk menjaga kesehatan lingkungan tempat tinggal walaupun ada beberapa rumah yang sudah sesuai dengan kriteria dengan tidak adanya media perkembangan jentik nyamuk. 
Penulis membantu mengatasi masalah kesehatan tersebut dengan dilakukan proses komunikasi yaitu diadakannya penyuluhan mengenai pencegahan demam berdarah yang sudah berjalan dengan baik. Dapat dibuktikan dengan pemaparan materi yang dapat diterima dan dipahami olehpeserta yang hadir dalam kegiatan edukasi, antusiasme peserta yang baik dengan bertanya kepada pemateri dan pemberian kritik dan saran dalam lembar feedback. Berdasarkan hasil kritik dan saran yang berikan, peserta sangat senang dengan adanya kegiatan edukasi seperti yang sudah dilakukan oleh penulis dikarenakan dapat membantu menambahnya pengetahuan mengenai demam berdarah yang terdiri dari definisi penyakit itu sendiri, tanda dan gejala khas, ciri dan tempat perkembangbiakan nyamuk Aedes aegypti, serta pencegahan yang dapat dilakukan dalam kehidupan sehari-hari. Pemberian hadiah kepada peserta yang dapat menjawab pada lembar feedback mengenaimateri yang disampaikan menjadi salah satu penilaian apakah penyampaian materi oleh anggota penulis dapat dipahami atau tidaknya oleh peserta yang hadir dalamkegiatan edukasi tersebut.

\section{Saran}

Dari pelaksanaan edukasi yang telah dilakukan penulis, dengan adanya kegiatan penyuluhan diharapkan dapat meningkatkan pengetahuan warga mengenai penyakit demam berdarah, meningkatkan kesadaran warga mengenai pentingnya pencegahan dari penyakit demam berdarah serta dapat menyikapi dan menerapkan pencegahan demam berdarah dalam kehidupan warga di Kelurahan Manyaran di Jalan Gedongsongo Barat II RT 02 RW 02. Selain itu, meningkatkan kesadaran warga di Jalan Gedongsongo Barat II RT 02 RW 02 Kelurahan Manyaran untuk dapat membersihkan lingkungan agar dapat mencegah penyakit demam berdarah.

Bagi mahasiswa diharapkan kegiatan ini mampu memanfaatkan kesempatan yang ada untuk dapat terjun langsung kepada masyarakat untuk melaksanakan promosi kesehatan dengan baik, serta melakukan tindak lanjut kepada masyarakat di Jalan Gedongsongo BaratII RT 02 RW 02 Kelurahan Manyaran yaitu pemantauan mengenai kebersihan lingkungan dalam mencegah penyakit demam berdarah yang dibantu oleh ketua RT di Jalan Gedongsongo Barat II RT 02 RW 02 Kelurahan Manyaran.

\section{Ucapan Terima Kasih}

Bagi mahasiswa diharapkan kegiatan ini mampu memanfaatkan kesempatan yang ada untuk dapat terjun langsung kepada masyarakat untuk melaksanakan promosi kesehatan dengan 
baik, serta melakukan tindak lanjut kepada masyarakat di Jalan Gedongsongo BaratII RT 02 RW 02 Kelurahan

\section{Daftar Pustaka}

1. Schaefer TJ, Panda PK, Wolford RW. Dengue Fever. [Updated 2020 Aug 23]. In: StatPearls [Internet]. Treasure Island (FL): StatPearls Publishing; 2021 Jan-. Available from: https://www.ncbi.nlm.nih.gov/books/NBK430732/

2. Fatmawati K, Windarto AP. Data Mining: Penerapan Rapidminer Dengan K- Means Cluster Pada Daerah Terjangkit Demam Berdarah Dengue (Dbd) Berdasarkan Provinsi. Comput Eng Sci Syst J. 2018;3(2):173.

3. Rokom. Data Kasus Terbaru DBD di Indonesia. Kementrian Kesehatan Indonesia. 2021. https://sehatnegeriku.kemkes.go.id/baca/umum/20201203/2335899/data- kasus-terbaru-dbdindonesia/

4. Badan Pusat Statistik Kota Semarang. Data Sensus Kepadatan Penduduk (Jiwa/km2). https://semarangkota.bps.go.id/indicator/12/48/1/kepadatan- penduduk.html

5. Susilowati, Dwi. Promosi Kesehatan. Cetakan Pertama. Jakarta: Kementrian Kesehatan Republik Indonesia. 2016.

6. Fakhriadi, Rudi, Fahrini Yulidasari, Ratna Setyaningrum. Faktor Risiko Penyakit Demam Berdarah Dengue di Wilayah Kerja Puskesmas Guntunng Payung Kota (Tinjauan Terhadap Faktor Manusia, Lingkungan, dan Keberadaan Jentik) Jurnal Publikasi Kesehatan Masyarakat Indonesia, Vol. 2 No. 1, April 2015.

7. Dinas Kesehatan Provinsi Jawa Tengah. Capaian Restra Tahun 2016. Semarang. 2017

8. Dinas Kesehatan. Profil Kesehatan Semarang. Dinas Kesehatan Semarang. 2018

9. Wahyono, Tri Yunis Miko et al. Faktor-Faktor yang Berhubungan dengan Kejadian Demam Berdarah dan Upaya Penanggulangannya di Kecamatan Cimanggis, Depok, Jawa Barat dalam Buletin Jendela Epidemiologi. Volume 2 Agustus 2010.

10. Kemenkes RI. 2017. Pedoman Pencegahan dan pengendalian Demam Berdarah Dengue di Indonesia. Jakarta : Kementrian Kesehatan RI

11. Antony J, Celine T. A descriptive study on dengue fever reported in a Medical College Hospital. Sahel Med J. 2014;17(3):83.

12. Made Susila Utama I, Lukman N, Sukmawati DD, Alisjahbana B, Alam A,

13. Murniati D, et al. Dengue viral infection in Indonesia: Epidemiology, diagnostic challenges, and mutations from an observational cohort study. PLoS Negl Trop Dis. 2019;13(10):1-19. 
14. Wirakusuma I. Gambaran tingkat pengetahuan, sikap, dan Praktik tentang pencegahan demam berdarah dengue di wilayah kerja Puskesmas Bebandem. MENARA Ilmu. 2016;8(4):169-76.

15. Kemenkes RI. 2019. Upaya Pencegahan DBD dengan 3M Plus. Jakarta : Kemenkes 